\title{
Therapeutic role of bone marrow-derived stem cells and zinc sulfate for reduction of liver fibrosis
}

\author{
Arsheema Kazmi ${ }^{1}$, Abeer Kazmi ${ }^{2,}{ }^{*}$, Sulaiman Shams ${ }^{1}$, Abdul Sajid ${ }^{3}$, Khalid Khan ${ }^{4}$
}

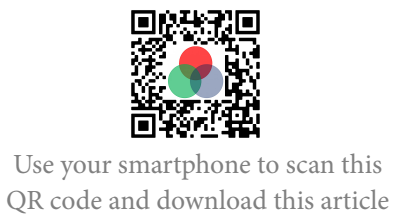

${ }^{1}$ Stem Cell Regenerative Medicine Lab, Department of Biochemistry, Abdul Wali Khan University Mardan-23200, Khyber Pakhtunkhwa, Pakistan

${ }^{2}$ Department of Biotechnology, Abdul Wali Khan University Mardan-23200, Khyber Pakhtunkhwa, Pakistan

${ }^{3}$ College of Veterinary Sciences and Animal Husbandry, Abdul Wali Khan University Mardan-23200, Khyber Pakhtunkhwa, Pakistan

${ }^{4}$ Specified PCR laboratory of Center of poultry and parasitology, Veterinary research Institute, Peshawar, Pakistan

\section{Correspondence}

Abeer Kazmi, Department of Biotechnology, Abdul Wali Khan University Mardan-23200, Khyber Pakhtunkhwa, Pakistan

Email: Abeer_Kazmi@yahoo.com

History

- Received: 2019-10-23

- Accepted: 2019-11-27

- Published: 2019-12-21

DOI : 10.15419/psc.v6i1.406

\section{Check for updates}

\section{Copyright}

(c) Biomedpress. This is an openaccess article distributed under the terms of the Creative Commons Attribution 4.0 International license.

\begin{abstract}
Introduction: Hepatic fibrosis is considered as the initial state of any chronic hepatic disease; progression causes accumulation of extracellular matrix (ECM) and develops into cirrhosis. In case of liver failure, transplantation was considered as the only suitable therapy but due to the hurdles in transplantation, therapy using stem cells was promoted. Mesenchymal stem cells (MSCs) are widely used for the treatment of a variety of diseases. Oxidative stress at the damage site causes poor MSC proliferation and engraftment. Thus, it is necessary to induce antioxidants with MSCs to enhance potency. Methods: To explore the therapeutic potential of zinc sulfate $\left(\mathrm{ZnSO}_{4}\right)$ and MSCs on carbon tetra chloride $\left(\mathrm{CCl}_{4}\right)$-induced hepatic toxicity, 6-8 week-old female albino mice $(B A L B / C)$ were used. Initially, mice were infected with $\mathrm{CCl}_{4}$ and then intra-peritoneally injected with MSCs only, $\mathrm{ZnSO}_{4}$ only, or a combination of $\mathrm{MSCs}_{\text {and }} \mathrm{ZnSO}_{4}$. MSCs were isolated from femur and tibia of mice, and were cultured under control conditions. Results: The morphological results revealed that in contrast to $\mathrm{MSC}$-only therapy, $\mathrm{ZnSO}_{4}$ enhanced the therapeutic potential of MSCs when administered to $\mathrm{CCl}_{4}$-injured mice. Biochemically, level of serum Alanine Transaminase (ALT) and total bilirubin was found to be significantly decreased in $\mathrm{ZnSO}_{4}+\mathrm{MSC}$ transplanted mice. Histopathological examination also revealed that $\mathrm{ZnSO}_{4}+\mathrm{MSC}$ transplantation induced a strong anti-apoptotic effect on $\mathrm{CCl}_{4}$-injured liver. Reverse transcription polymerase chain reaction (RT$\mathrm{PCR}$ ) detected a noteworthy anti-fibrotic effect of $\mathrm{MSC}$ in the presence of $\mathrm{ZnSO}_{4}$, down-regulation of apoptotic marker (Bax), and up-regulation of anti-apoptotic ( $\mathrm{BCl}$-xl) and hepatic (Albumin) markers. Conclusion: Thus, it was concluded that the presence of $\mathrm{ZnSO}_{4}$ reduced oxidative stress, enhanced the proliferation rate of MSCs, and significantly attenuated hepatic fibrosis.
\end{abstract}

Key words: Albumin, Bax, Bcl-xl, Liver Fibrosis, Mesenchymal stem cells, Zinc sulfate, $\beta$-Actin

\section{INTRODUCTION}

Liver is one of the largest organs and central metabolic hub of the human body. Hepatocytes are the main building block of the liver and perform a variety of functions, such as protein synthesis, detoxification, carbohydrate, lipid metabolism and bile production. Hepatic fibrosis is the trademark of any chronic liver disease and is the major cause of morbidity and mortality. Cirrhosis is the final-stage of hepatic disease which occurs when the fibrotic tissues replace the healthy tissues ${ }^{1}$. In liver fibrosis, repeated injury causes tissue alteration, which is observed by extreme production of extracellular matrix (ECM) with the formation of scar tissue covering the region of disease $^{2}$. The main causes of liver fibrosis are alcohol usage, viral hepatitis B and C (HBV and HCV), hepatitis due to autoimmune disorder, obesity, diabetes, parasitic disorder, metabolic disorder, biliary disease, as well as vulnerability to toxins, chemicals and drugs ${ }^{3}$. It was reported globally that liver cirrhosis was a major cause of over one million deaths in 2010, equivalent to $2 \%$ of all deaths globally ${ }^{4}$. Chronic liver dis- eases account for 1 in 40 deaths worldwide ${ }^{5}$. Hepatocytes have a remarkable efficiency to repair the infected liver and restore its normal functionalities; when the inherent power of repairing hepatocytes is lost, liver transplantation remains the only efficient treatment. This procedure is highly invasive and limited due to the scarcity of donors, it is not exempt of complications $^{6}$.

Nowadays, stem cells (SCs) are broadly used for the regeneration of hepatocytes. The high potency of cell multiplication and multipotency are the primary characteristics of a stem cell. The proliferation and differentiation capability of stem cells depends on the source and type of stem cells, and is referred to as "stemness" 7 . If suitable conditions with accurate signals are provided, stem cells can differentiate into variety of cell types and lead to formation of organs and, finally, a complete organism. Therefore, SCs have valuable properties for regenerative medicine ${ }^{8}$. Based on differentiation, SCs are classified into totipotent, pluripotent, multipotent or unipotent ${ }^{9}$, while based on source and properties, 
they are categorized into embryonic SCs (ESCs), induced pluripotent SCs (iPSCs), and non-embryonic SCs/adult stem cells (ASCs) ${ }^{10}$.

ESC therapy has some limitations; these include safety and ethical issues, as their acquirement involves the destruction of embryos due to which ethical concerns are raised. Due to this limitation of ESCs, ASCs provide another platform for therapy of liver diseases, especially bone marrow derived stem cells (BMSCs) ${ }^{11}$. ASCs also have the ability of proliferation, differentiation and regeneration of tissues ${ }^{12}$. ASCs are classified into hematopoietic stem cells (HSCs) which are blood-forming cells, and Mesenchymal Stem Cells (MSCs), which are somatic-forming cells. It had been thought that HSCs in the bone marrow could not differentiate into the variety of cells, such as nerve cells in the brain.

MSCs have the ability of self-renewal and differentiation into a variety of cell types. MSCs have fibroblastic appearance with multipotent nature and can be isolated from a wide range of tissues but bone marrow and gingiva are the key sources of MSCs ${ }^{13,14}$. There, MSCs are responsible for the maintenance of the microenvironment (niche) and provide support to HSCs in the bone marrow ${ }^{15}$. MSCs can also be differentiated into hepatocytes to treat different types of liver disease $^{16,17}$.

Oxidative stress is a pathogenic mechanism, whereby exposure of the liver to oxidative stress damages the liver and leads to hepatic fibrosis. Cell damage increases with the increase in concentration of reactive oxygen species (ROS) in the liver. The use of antioxidants reduces the amount of these free radicals ${ }^{18}$. Enzymes involved in the synthesis and breakdown of carbohydrates, lipids, proteins and nucleic acids, and in the metabolism of other micro-nutrients, contain zinc as one of their key components. Zinc has been demonstrated to protect against hepatotoxicity produced by a variety of chemicals ${ }^{19}$.

The aim of the present study was to investigate the therapeutic potential of MSCs, in the presence of $\mathrm{Zn}$, against $\mathrm{CCl}_{4}$-induced liver toxicity in mice.

\section{METHODS}

\section{Preparation of animals}

Six to 8 week-old female albino mice $(B A L B / c)$, with weight ranging from 25-30 g, were bought from the Directorate of Veterinary Research Institute, Peshawar, Pakistan. All mice were housed in a pathogen-free environment at optimum temperature (20-25 $\left.{ }^{\circ} \mathrm{C}\right)$ and were provided a standard rodent diet with appropriate cycle of light and dark. The Bioethics
Committee of the Biochemistry Department, $\mathrm{Ab}$ dul Wali Khan University, Mardan (AWKUM) approved all the laboratory procedures. For therapeutic treatment of liver fibrosis, different mouse treatment groups were assigned, such as positive control group (only infected with $\mathrm{CCl}_{4}$ ), negative control group (untreated group), MSC-only treated group, Zn-only treated group, and MSC $+\mathrm{Zn}$ treated group. Three mice were used for each group (triplicates) and a few were used to isolate bone marrow cells. Initially, $\mathrm{CCl}_{4}$ was injected in the body of mice via intra-peritoneal route, at a dose of $1 \mu \mathrm{l} / \mathrm{g}$ (do you mean $1 \mu \mathrm{g} / \mathrm{ml}$ ) per gram body weight, dissolved in an equal volume of olive oil (1:1 ratio). The injection was given with $1 \mathrm{ml}$ insulin in syringe- twice a week for 4 weeks- to induce hepatic fibrosis.

\section{Isolation and characterization of MSCs}

MSCs were isolated from femur and tibia of Balb/C mice according to the protocol described by Khan et $a l .{ }^{20}$, and were cultured in Dulbecco's Modified Eagle's Medium (DMEM) (Gibco/Thermo Fisher Scientific, Waltham, MA, USA), supplemented with $10 \%$ fetal bovine serum (FBS) (Biowest, Nuaillé, France) and $100 \mathrm{IU} / \mathrm{ml}$ penicillin and $100 \mu \mathrm{g} / \mathrm{ml}$ streptomycin (both from Capricorn Scientific, Ebsdorfergrund, Germany) in 25-mm culture flasks. The culture was maintained in a humidified incubator supplied with $5 \% \mathrm{CO}_{2}$ at $37^{\circ} \mathrm{C}$. The stem cells were characterized as MSCs by the method described by Oyagi et al. ${ }^{21}$. After 3 days of culturing, in each flask the medium was removed completely and washed with PBS (twice) to remove non-adherent cells (HSCs) while the adherent cells (MSCs) remained attached. After washing, fresh medium was replenished in the culture flask, which was then placed back into the incubator for proliferation of MSCs.

\section{Transplantation of MSCs and $\mathrm{Zn}$ in mice}

For transplantation of MSCs, firstly, the cells were isolated from the cultured flasks. For cell detachment trypsin (1x) was added into the culture flask for 5-10 minutes. Then, the cells were centrifuged at $5000 \mathrm{rpm}$ for 10 minutes. After centrifugation, the supernatant was discarded and the pellet diluted in 100-200 $\mu \mathrm{l}$ of PBS. The pellet containing about $1 \times 10^{6}$ MSCs in $1 \mathrm{ml}$ syringe was used for transplantation.

Mice from MSC-treated group received MSCs $\left(1 \times 10^{6}\right.$ cells in $1 \mathrm{~mL}$ PBS) at a dose of $1 \times 10^{6}$ cells/100 $\mu \mathrm{l} \mathrm{PBS} / \mathrm{mouse}$ through the mouse tail portal vein. Zinc-treated mice were injected with $100 \mu \mathrm{l} /$ mice 
$\mathrm{ZnSO}_{4} .7 \mathrm{H}_{2} \mathrm{O}$ intra-peritoneally, whereas mice from $\mathrm{MSC}+\mathrm{Zn}$ treated group receive a dose of 100 $\mu \mathrm{l} / \mathrm{mice}^{\mathrm{ZnSO}} 4.7 \mathrm{H}_{2} \mathrm{O}$ with MSCs $\left(1 \times 10^{6}\right.$ cells $/ 100 \mu \mathrm{l}$ $\mathrm{PBS} /$ mouse), also through the tail portal vein.

\section{Biochemical analysis}

After dissection of the mice, blood samples were collected from the hearts of mice of each group through 1 $\mathrm{ml}$ syringe. The blood was centrifuged at $8000 \mathrm{rpm}$ for $10 \mathrm{~min}$ to isolate the serum. Serum ALT and bilirubin levels were determined through spectrophotometer using commercial kits (Vitro Scient, Inc., Cairo, Egypt).

\section{Histopathological analysis}

After excising the mouse liver from each animal, the hepatic tissues were fixed in $10 \%$ formalin. After $24-$ $72 \mathrm{~h}$ of fixation, the tissues were moved to different degrees of alcohol for dehydration. Then, the paraffin sections were prepared and cut into $5-\mu \mathrm{m}$ sections by a rotary microtome (ROBUS). After bathing in gelatin-containing ultrapure water, the sections were made with the help of microscopic slides and allowed to dry at $37^{\circ} \mathrm{C}$ overnight. Then, the sections were stained with hematoxylin $(\mathrm{H})$ and eosin (E) reagents. The sections were studied through a microscope at 10X magnification for histological changes (i.e. apoptosis and collagen deposition).

\section{qPCR analysis for gene expression}

RNA was isolated from liver tissue homogenate using Trizol kit (Invitrogen, Carlsbad, CA, USA). After isolation of RNA, cDNA was synthesized through RT-PCR using $2 \mu \mathrm{g}$ of RNA and oligo-dT primers at $42^{\circ} \mathrm{C}$ for 60 minutes using a kit (Invitrogen). The purity/concentration of RNA and cDNA was checked using Nanodrop spectrophotometer (COLIBRI, TITERTEK BERTHOLD). Next, 100-500 ng/ml of cDNA was amplified through PCR using a standard PCR kit. The sequences of the primers are indicated in Table 1. The qPCR protocol consisted of $40 \mathrm{cy}-$ cles at $94^{\circ} \mathrm{C}$ for 4 minutes, $56^{\circ} \mathrm{C}-58^{\circ} \mathrm{C}$ for $45 \mathrm{sec}$, and $72^{\circ} \mathrm{C}$ for $30 \mathrm{sec}$, followed by a final extension step at $72^{\circ} \mathrm{C}$ for 10 minutes. Gene expression levels of hepatic marker (Albumin) and apoptotic marker (Bax) were evaluated at the mRNA level by RT-PCR in all mouse samples using Biorad CFX96 Software. In this study, $\beta$-actin was used as a reference marker. Expression levels of Bax, Bcl-xl, and Albumin in the different mouse groups were different, whereas the expression level of $\beta$-actin was constant in all groups.
Therefore, $\beta$-actin was used as standard and the expression level of each of the other markers was compared to it; the relative expression of the target genes was determined by comparing to the reference gene $(\beta$-actin).

\section{Bradford assay analysis}

Whole protein was isolated from liver using Trizol method (Invitrogen) and BSA was used as a standard protein. Six different dilutions of BSA were prepared in PBS, along with the sample protein. Each cuvette contained $1 \mathrm{ml}$ of standard solution and 1.5 $\mathrm{ml}$ of Bradford reagent. This was followed by incubation at room temperature for $10 \mathrm{~min}$. Then, the absorbance of each cuvette was measured at $595 \mathrm{~nm}$. The graph for standard curve values was plotted (the $\mathrm{x}$-axis represented the micrograms of standard protein and the y-axis represented the absorbance reading at $595 \mathrm{~nm}$ ). The sample protein absorbance was quantified using the same above method and the unknown protein concentration was calculated by comparison to the standard protein.

\section{Statistical analysis}

Standard errors $( \pm)$ and mean values of various treatments were determined by analysis of variance (ANOVA). Significant difference was separated using Duncan's multiple range test, set at $\mathrm{P} \leq 0.05$.

\section{RESULTS}

\section{Isolation and characterization of MSCs}

After the removal of tibia and femur bone from the dissected mice, bone marrow cells were isolated by flushing prepared media through it (Figure 1 B-E). Bone marrow cells were centrifuged at $8000 \mathrm{rpm}$ for 10 min along with media to collect the cell pellet formed at the bottom. Bone marrow mainly consists of two types of cells: HSCs and MSCs. The adherent property of MSCs allow them to become attached to the surface of culture flasks. After 3 days, the medium was discarded and the flask was washed with PBS to remove non-adherent cells (i.e. HSCs); adherent cells were fed with fresh DMEM. This process was carried on until the cells were between 70-90\% confluence. Hepatocyte growth factor (HGF) was not added to the medium, therefore the MSCs were not differentiated into hepatocytes, specifically. The successful proliferation of MSCs was investigated through a hemocytometer; moreover, about $1 \times 10^{6}$ MSCs were taken into a $1 \mathrm{ml}$ syringe and transplanted into the tail vein of fibrotic mice. Mice were dissected after 10 days 
Table 1: Primers with their sequence, annealing temp and product size

\begin{tabular}{|c|c|c|c|}
\hline PCR primer & Sequence (5'-3') & $\begin{array}{l}\text { Annealing } \\
\text { temperature }\end{array}$ & $\begin{array}{l}\text { Size in } \\
\text { bp }\end{array}$ \\
\hline Albumin (F) & GCTGTAGTGGATCCCTGGTG & $56 \circ \mathrm{C}$ & 196 \\
\hline $\operatorname{Albumin}(\mathrm{R})$ & GCTGTAGCCTTGGGCTTG & & \\
\hline $\operatorname{Bax}(\mathrm{F})$ & TGGAGATGAACTGGACAGCA & $58 \circ \mathrm{C}$ & 152 \\
\hline $\operatorname{Bax}(\mathrm{R})$ & CAAAGTAGAAGAGGGCAACCAC & & \\
\hline$B c l-x l(\mathrm{~F})$ & TTCGGGATGGAGTAAACTGG & $58 \circ \mathrm{C}$ & 150 \\
\hline$B c l-x l(\mathrm{R})$ & AAGGCTCTAGGTGGTCATTCAG & & \\
\hline$\beta$-actin (F) & GCTGTGTTGTCCCTGTATGC & $58 \circ \mathrm{C}$ & 106 \\
\hline$\beta$-actin (R) & GAGCGCGTAACCCTCATAGA & & \\
\hline
\end{tabular}

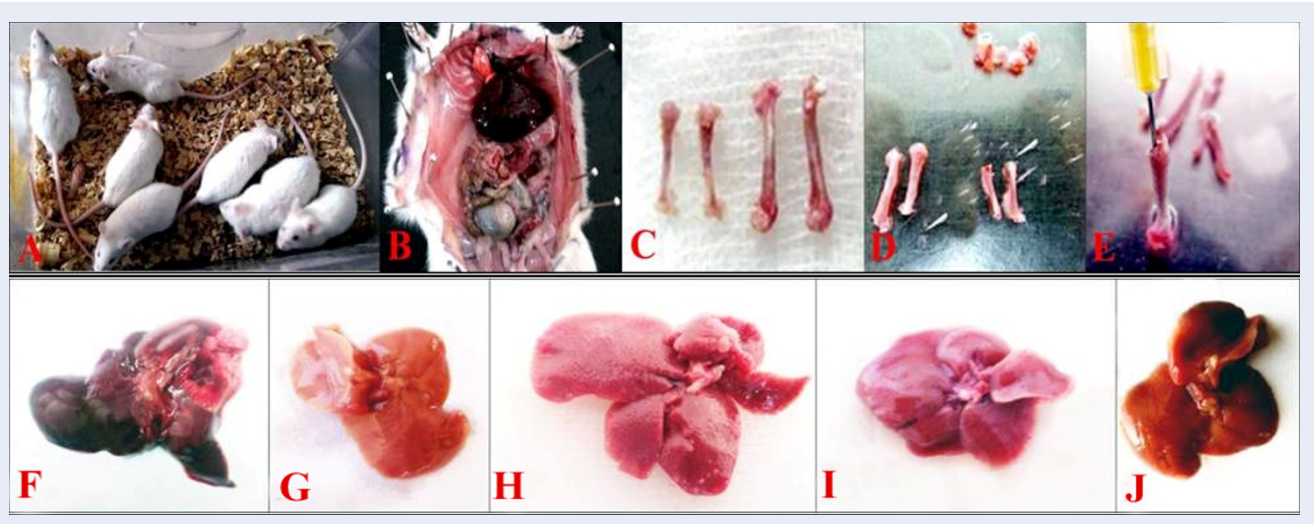

Figure 1: 6-8 weeks aged albino mice (BALB/C) weight ranging from 25-30 $\mathrm{g}(\mathrm{A})$, mice dissection $(\mathrm{B})$, isolated tibia and femur bones (C), removal of joints from bones (D), bone marrow isolation (E), comparative analysis of liver morphology of negative control (F), positive control (G), MSCs treated (H), Zinc treated (I) and MSCs + Zinc treated $(\mathrm{J})$.

of transplantation. After dissection, liver tissues and blood were collected to assess the level of hepatic fibrosis regeneration.

\section{Comparative analysis of hepatic morphol- ogy}

The hepatic morphology of all the groups of mice was studied. In MSC $+\mathrm{Zn}$ treated group of mice, the liver morphology was more similar to that of the negative control mouse group (Figure $\mathbf{1} \mathbf{F}$ ), than to the other treatment groups. The livers of MSC $+\mathrm{Zn}$ treated mice were reddish in color, with smooth surface and less scarring (Figure 1J). The liver morphology of the positive control mice was more brownish and pale in color, and shrinkage in structure could be seen (Figure 1G). However, the morphological response of the livers of the mouse group treated with MSCs only or Zinc only, revealed a moderate reduction in hepatic fibrosis with less reddish black color, rough sur- face and few fibrotic scars. Hepatic morphological results clearly indicated that MSCs- in the presence of Zinc- was more effective in reducing by fibrosis.

\section{Biochemical tests of hepatic function}

Serum levels of ALT and bilirubin were compared across all groups of mice using ALT and bilirubin kits (Vitro Scient).

The serum level of ALT in mice treated with MSCs + Zinc was significantly lower $(66.63 \pm 9.24$ units/L) as compared to the positive control group $(297.03 \pm 10.3$ units/L), MSC-treated group (indicate the values), or Zinc-treated group (indicate the values) (Figure 2A). The ALT value in the positive control mouse group revealed that there was remarkable incline in ALT (liver enzyme) level. ALT value of MSC $+\mathrm{Zn}$ treated group of mice was closer to the mean value of the negative control ( $56.43 \pm 6.8$ units/L), indicating normalization of hepatic functions (Figure $2 \mathrm{~A}$ ).

Serum bilirubin level was also analyzed in all groups of mice. The level of total bilirubin is an indicator for 

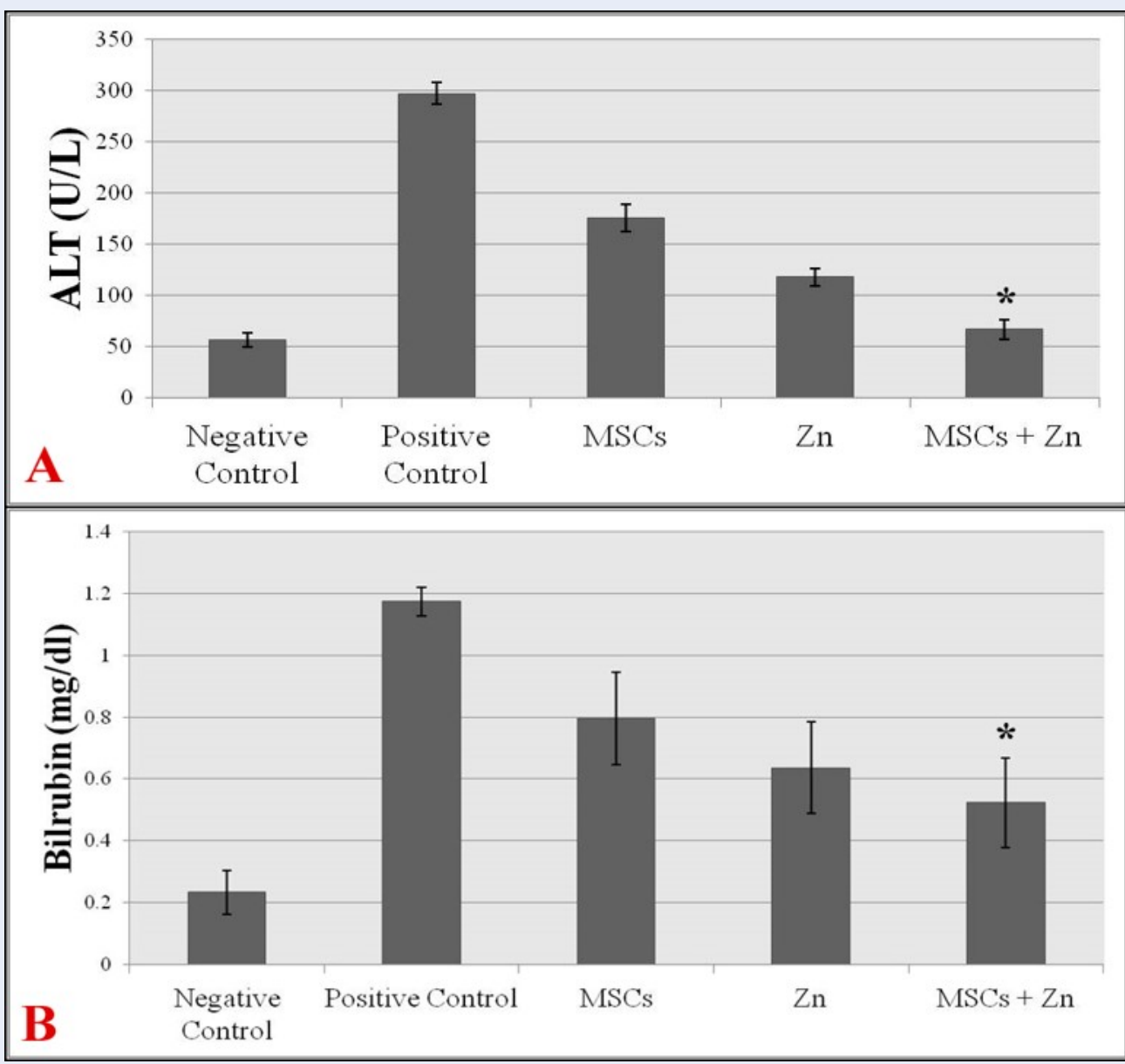

Figure 2: Liver function analysis; level of serum ALT in all treatments (A), level of serum total bilirubin in all treatments (B).

apoptosis; the higher the level of bilirubin, the higher the injury status. This sort of trend was observed when total bilirubin level was detected in all samples. The highest bilirubin level was recorded in the positive control mouse group. However, a significant decline in the serum level of bilirubin was recorded in MSC-only and Zinc-only treated groups of mice. The lowest level of serum bilirubin was recorded in MSCs + Zinc treated group of mice $(0.52 \pm 0.14 \mathrm{mg} / \mathrm{dl})$, which was even notably lower than that of the positive control group (1.17 $\pm 0.04 \mathrm{mg} / \mathrm{dl}$ ) (Figure $2 \mathrm{~B}$ ). These results clearly indicate that MSCs, in the presence of Zinc, have high ability to reduce liver fibrosis by reducing the apoptotic effect.

Histopathological analysis of hepatic fibrosis

Liver sections of all groups of mice were stained with standard hematoxylin and eosin (H\&E) stain, as shown in Figure 3. The liver sections of the positive control mice had an abundance of hepatocytic apoptosis, which was represented by the irregularly-shaped individual cells with hyper-eosinophilic cytoplasm and fragmented nuclei with more central vein congestion and higher liver collagen deposition (Figure 3B). Mice treated with only MSCs and only zinc revealed a moderate level of reduction in apoptosis, vein congestion and collagen deposition (Figure $\mathbf{3}$ C and D). The livers of MSC-only and zinc-only treated mice showed a remarkable decrease in liver collagen, central vein congestion, and number of apoptotic hepatocytes. A comparative study demonstrated that the liver sections of MSC $+\mathrm{Zn}$ treated mouse group were more similar to that of the negative control mouse group, indicating that the liver had showed signs of restoring its normal functioning (Figure 3). 


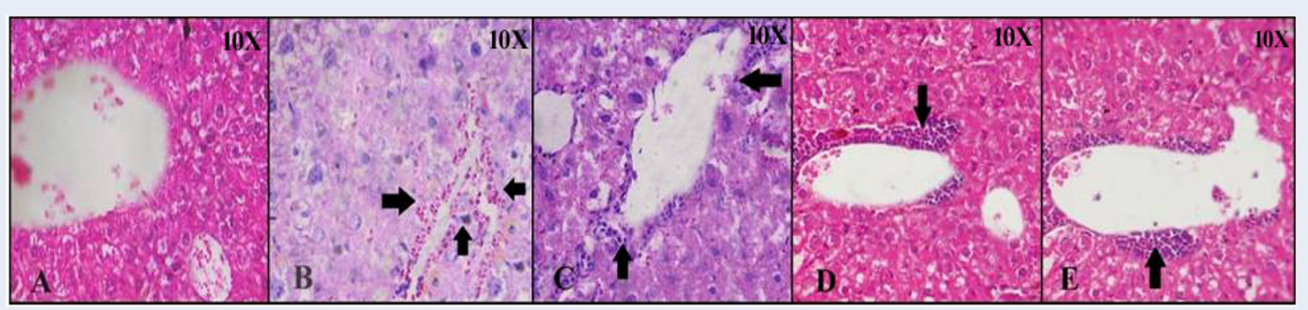

Figure 3: Histopathological analysis of fibrotic liver of treated and untreated mice (10X). Negative control (A), Positive control (B), MSCs treated (C), Zinc treated (D), MSCs + Zinc treated (E).

\section{Gene expression analysis}

The levels of apoptotic, anti-apoptotic, and hepatocyte marker expression were analyzed for all the samples by real-time PCR. In this study, $\beta$-actin was used as a reference marker. The expressional levels of Bax, $B c l-x l$ and Albumin across the different groups were different, whereas the expression level of $\beta$-actin was constant in all groups. Therefore, $\beta$-actin was used as a standard, and the expression level of the other markers was compared to it.

The expression of Bax marker was down-regulated in MSC + Zn treated group (1.54 \pm 0.15$)$, as compared to the positive control group (4.7 \pm 0.3$)$, MSC-treated group ( $3 \pm 0.3$ ), and Zinc-treated group (2.9 \pm 0.2 ). However, the reduction in expression of Bax marker in MSC-only or Zinc-only treated groups of mice was quite similar to that of the positive control group; however, a significant reduction was detected in MSC $+\mathrm{Zn}$ treated mice.

$B c l-x l$ is an anti-apoptotic marker; higher expression of this marker indicates normal functioning of the liver. The expression of $B c l-x l$ marker was upregulated in MSC + Zn treated group (5.80 \pm 0.4$)$, similar to that of the negative control group $(6.36 \pm 0.3)$, whereas the lowest expression of $B c l-x l$ marker was recorded in the positive control group. Significant levels of $B c l-x l$ expression were also observed for MSC-only or Zinconly treated groups (Figure $4 \mathrm{C}$ ).

Maximum regulation of albumin (a hepatocyte marker) was recorded in the MSC $+\mathrm{Zn}$ treated group of mice (1.86 \pm 0.1$)$. Similar to the $B c l-x l$ marker, the albumin marker also displayed an elevated expression in the MSC-only and Zinc-only treated groups, as compared to the positive control group (Figure 4 D).

After analyzing the expression of $\beta$-actin through RTPCR, the results showed that $\beta$-actin expression in all experimental groups was similar and, thus, it was used as a standard (mean of $16.46 \pm 1.36$ ). The expression levels of all other markers were compared with $\beta$ actin to determine expression level of $B a x, B c l-x l$ and albumin, in the different groups to analyze the effect of $\mathrm{CCl}_{4}$, MSCs only, Zinc only, and MSC $+\mathrm{Zn}$ on the experimental mouse groups.

\section{Bradford assay analysis}

The protein concentration was greater in the positive control group due to deposition of ECM proteins, including collagen fibers. Free radicals were formed due to induction of $\mathrm{CCl}_{4}$, which was involved in the depletion of glutathione (GSH). The absorbance of samples from MSC $+\mathrm{Zn}$ treatment was $0.28 \mathrm{~nm}$, which was close to the absorbance for negative control (Figure 5). The absorbance values of the unknown concentration samples were plotted on the graph to determine the concentration. The concentration of positive control $(50 \mu \mathrm{g} / \mathrm{ml})$ was greater than the treated groups due to degradation of ECM in the treated groups. The concentration of negative control was $10 \mu \mathrm{g} / \mathrm{ml}$, MSC-treated group was $40 \mu \mathrm{g} / \mathrm{ml}$, Zntreated group was $30 \mu \mathrm{g} / \mathrm{ml}$, and MSC + Zinc treated group was $20 \mu \mathrm{g} / \mathrm{ml}$.

\section{DISCUSSION}

Excessive accumulation of fibrillar ECM leads to development of hepatic fibrosis. This ECM is gradually replaced by interstitial collagens, particularly collagens I and III, proteoglycans, and fibronectin ${ }^{22}$. Due to excessive production of fibrillar collagen and fibronectin, the normal architecture of the liver can become disrupted; these changes can lead to abnormal functioning of hepatocytes and parenchymal cell damage $^{23}$. Previous studies have shown that MSCs have been used for the treatment of both acute and chronic liver diseases. There is a body of clinical and experimental evidence that confirms that transplantation of MSCs can restore the liver's normal functions in acute and chronic hepatic diseases ${ }^{24}$.

Besides its other functions, the lover also plays a vital part in the maintenance of zinc homeostasis- as a rapid exchanging repository for zinc storage. Hepatic diseases are also a cause of alteration in $\mathrm{Zn}$ levels; 


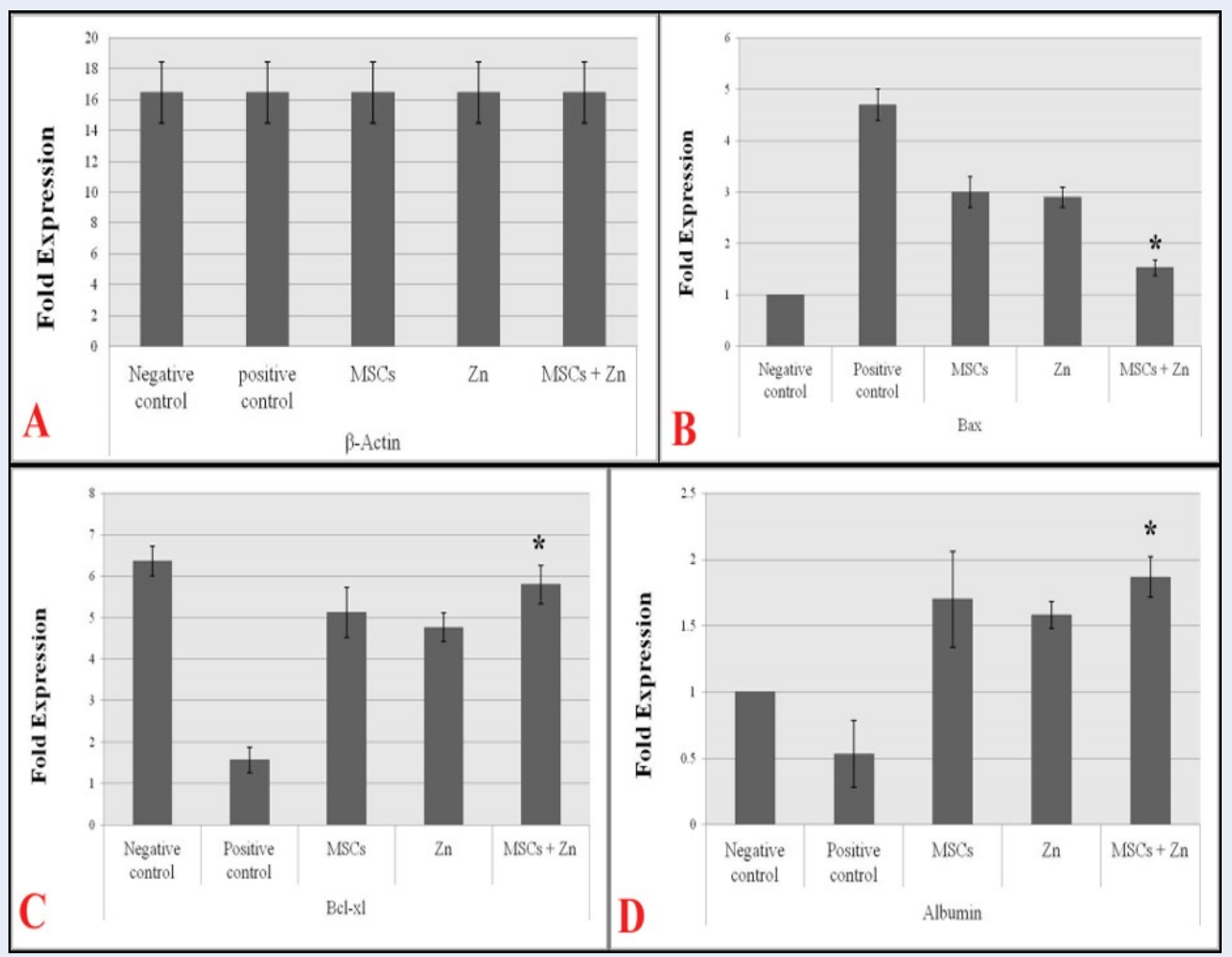

Figure 4: Comparative analysis of different genes expression in treated and untreated mice. Comparison of $\beta$-actin expression (A), Comparison of Bax gene expression (B), Comparison of BCl-xl expression (C), Comparison of albumin expression (D).

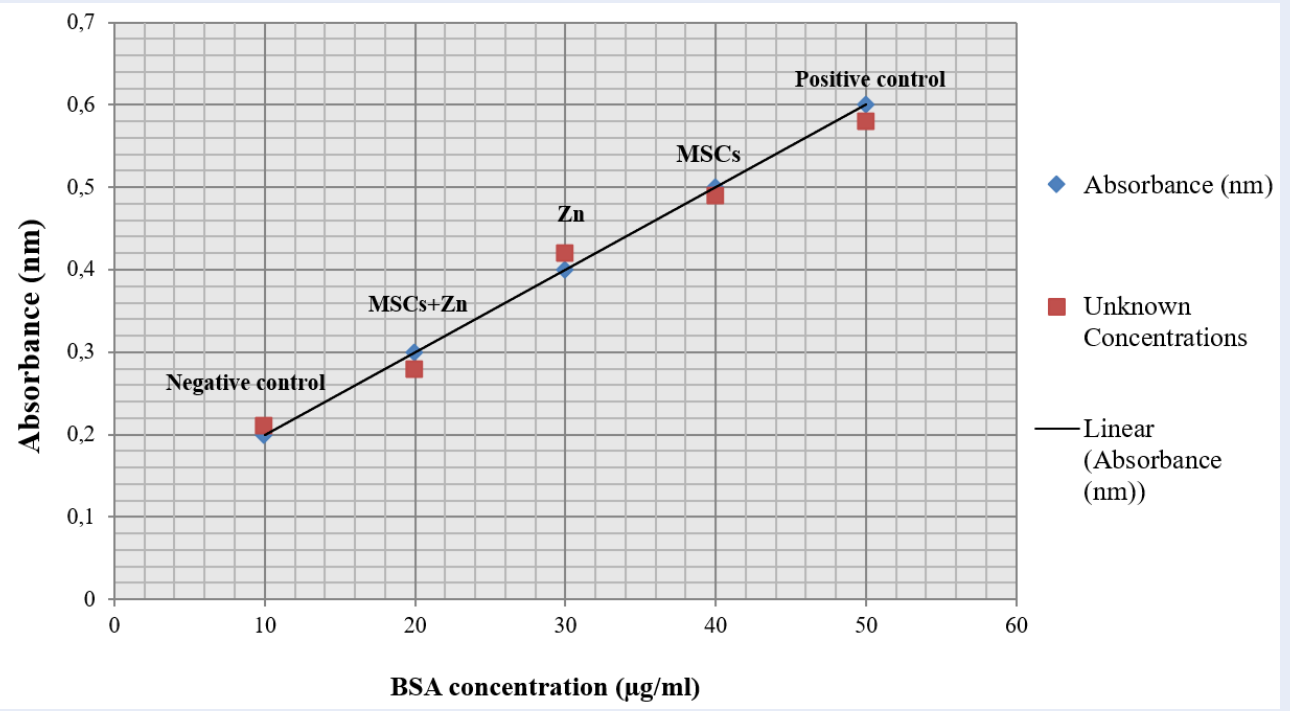

Figure 5: Graph between absorbance and concentration, determination of total protein concentration in unknown sample using Bradford assay. 
low $\mathrm{Zn}$ level in the liver is related with disturbed liver function and regeneration. Zinc deficiency was found to be increased in an animal model of acute liver injury which was stimulated by a hepatotoxic agent (i.e. carbon tetrachloride; $\left.\mathrm{CCl}_{4}\right)^{25}$. The properties of $\mathrm{Zn}$ are protection against vitamin $\mathrm{E}$ depletion, stabilizing membrane structure, inhibiting endogenous free radical production, contribution to the structure of extracellular superoxide dismutase, and protection of DNA from damage (as it is a component of many DNA repair proteins) ${ }^{26}$.

Membranes of $\mathrm{Zn}$-deficient cells were found to be rich in concentrations of malondialdehyde (MDA), and it has clearly been indicated that peroxidation of membrane phospholipids take place more in those cells which have less zinc concentration. Hepatic lipid peroxide development and proline hydroxylase activity can be down-regulated by the injection of $\mathrm{Zn}$ this is because liver has an active role in $\mathrm{Zn}$ metabolism and tissues mount up $\mathrm{Zn}$ in the form of $\mathrm{Zn}$ metallothionein (MT) ${ }^{27}$.

These two mechanisms are implicated in the defensive effect of $\mathrm{Zn}$ against $\mathrm{CCl}_{4}$ toxicity. Zinc inhibits the expression of CYP2E1, preventing toxic CYP-derived $\mathrm{CCl}_{4}$ metabolites formation; this mechanism was shown in a previous study in which $17 \%$ repression of CYP2E1 mRNA expression by $\mathrm{Zn}$ was reported. The second possible mechanism is that $\mathrm{Zn}$ is the central component of metallothionein, which shows antioxidant action against reactive oxygen species by removing the free radicals ${ }^{28}$.

Therefore, the present work follows up on previous data; in this study, we hypothesized that the combined effect of MSCs and Zn would minimize oxidative stress and also enhance the regeneration of the fibrotic liver. In the present study, MSCs were isolated and transplanted into infected mice- in presence of $\mathrm{Zn}$. Zinc enhanced the proliferation frequency of cells and caused considerable beneficial effects on liver fibrosis (induced by $\mathrm{CCl}_{4}$ ) in mice.

ROS reacts with sulfhydryl groups, such as GSH, protein thiols and antioxidant enzymes, and causes deleterious effects on them. The excessive production of free radicals causes membrane lipid peroxidation and they bind to larger biological molecules ${ }^{29}$. In $\mathrm{CCl}_{4}$-treated rats, the hepatic content of GSH was extremely reduced, while MSCs increased hepatic GSH content and entirely stopped their inhibition ${ }^{30}$. An antioxidant with hepatoprotective activity can be effective against hepatic damage, such as Careya arborea against $\mathrm{CCl}_{4}$ induced liver injury in rats ${ }^{31}$. In another study, $\mathrm{CCl}_{4}$-induced injury in mice was efficiently reduced by the pre-treatment of $\mathrm{Zn}^{28}$. The present results are in correlation with these findings; the optimum dose of zinc strongly enhances the antioxidant effect and proliferative ability of MSCs by increasing the hepatic MT content to normal levels in the liver tissue. This significantly reduces the concentration of free radicals and stops the succession of liver fibrosis. Rungruang et al. reported that normal mouse liver is reddish black in color, compared to normal mouse liver. Indeed, the liver of diseased mice is changed from a reddish black to a brownish black or pale color $^{32}$. Similar morphological results were observed in our studies. The liver morphology of MSC + Zinc treated group of mice showed more resemblance with the negative control mice- with reddish black color, in contrast to MSC-only or Zn-only treated groups of mice. The liver morphology of positive control mice was brownish pale in color (Figure 1). These morphological results demonstrate that MSCs- when combined with Zinc- have a remarkable antifibrotic effect on $\mathrm{CCl}_{4}$, as compared to MSC-only treatment.

AST and ALT activities were increased in plasma, with lipid accumulation and hepatocytic necrosis reported when rats were exposed to $\mathrm{CCl}_{4}{ }^{33}$. In the present work, compared to the positive control group, the liver enzymatic activity in MSC-only treated group was decreased. However, a significant reduction of liver enzymes to the normal levels was observed in MSC + Zinc treated group (Figure $2 \mathrm{~A}$ and $\mathbf{B}$ ).

Histological changes demonstrated that MSC transplantation recovered liver function and reversed hepatic necrosis, deposition of collagen, and inflammation ${ }^{34}$. The histopathological examination of $\mathrm{CCl}_{4}$ damaged livers exhibited a noteworthy increase in liver collagen adjacent to hepatic lobules, leading to large fibrous septa with central vein congestion and apoptotic hepatocytes. The combination of MSCs and Zinc showed considerable anti-apoptotic effects on liver with less collagen deposition (Figure 3).

Zinc sulfate increases the hepatic conversion of amino acids into urea, which indicates clinical and biochemical improvements. In alcoholic and hepatitis patients, the concentration of amino acids are high in contrast to control subjects ${ }^{35}$. The Bradford assay resembles in this study are in accordance with previous findings; that is, there was a clear reduction of total protein observed in the MSC $+\mathrm{Zn}$ treated group of mice, while the concentration of total protein was high in the positive control group.

The qPCR analysis demonstrated that the expression of apoptotic markers, such as Bax. was upregulated in $\mathrm{CCl}_{4}$-infected hepatocytes, while the ex- 
pression of anti-apoptotic marker, $B c l-x l$, was downregulated. In the same manner, it has been shown that the expression of hepatocyte marker, albumin , was inversely proportional to the concentration and duration of $\mathrm{CCl}_{4}$ treatment ${ }^{36}$, which are similar results to those observed in our present study. $\mathrm{Zn}$ and MSC transplantation significantly restored the abnormal expression of Bax, Bcl-xl, and albumin, as compared to MSC-only transplantation in $\mathrm{CCl}_{4}$-infected mice. Thus, the combination of $\mathrm{Zn}$ and MSCs facilitated high proliferation and regenerative capability of MSCs, as compared to MSC-alone transplantation, to diminish liver fibrosis.

\section{CONCLUSION}

Overall, from morphological, biochemical and histopathological results- along with Bradford assay and RT-PCR results- it can be concluded that BMSCs, in combination with zinc, had a high capacity to regenerate fibrotic liver and restore some of its normal functions. Zinc enhanced the regenerative ability of MSCs by increasing the proliferation rate of these cells for the reduction of liver fibrosis. Additionally, zinc displayed a strong antioxidant activity which regulated the enzymes present in the liver, such as glutathione and metallothionein, which neutralized free radicals and reduced the rate of hepatocyte damage. Due to these two reasons, the combination of zinc and MSC represents a potentially promising stem cell-based therapy for the treatment of liver fibrosis.

\section{CONFLICT OF INTEREST}

All the authors declared that they have no conflict of interest.

\section{ACKNOWLEDGMENT}

We thank Abdul Wali Khan University Mardan, Pakistan and DoST (Directorate of Science and Technology, KPK) for providing the financial support for the research work, DVRI (Directorate of Veterinary Research Institute), Peshawar and DVM (Department of Veterinary Medicines) University of Agriculture, Peshawar for providing research facilities

\section{ETHICAL STATEMENT}

The bioethics committee of Biochemistry Department, Abdul Wali Khan University, Mardan (AWKUM) approved all the laboratory procedures.

\section{DATA AVAILABILITY}

All the data of this research work are available in this manuscript.

\section{REFERENCES}

1. Byass $P$. The global burden of liver disease: a challenge for methods and for public health. BMC Med. 2014;12(1):159. PMID: 25286285. Available from: 10.1186/s12916-014-0159-5.

2. Lee D, Gil W, Lee $H$, Lee KW, S L, Kim S. Factors affecting graft survival after living donor liver transplantation. Transplant Proc. 2004;36(8):2255-6. PMID: 15561210. Available from: 10.1016/j.transproceed.2004.08.073.

3. Mormone E, George J, Nieto N. Molecular pathogenesis of hepatic fibrosis and current therapeutic approaches. Chem Biol Interact. 2011;193(3):225-31. PMID: 21803030. Available from: 10.1016/j.cbi.2011.07.001.

4. Mokdad AA, Lopez AD, Shahraz S, Lozano R, Mokdad AH, Stanaway J, et al. Liver cirrhosis mortality in 187 countries between 1980 and 2010: a systematic analysis. BMC Med. 2014;12(1):145. PMID: 25242656. Available from: 10.1186/ s12916-014-0145-y.

5. Perz JF, Armstrong GL, Farrington LA, Hutin YJ, Bell BP. The contributions of hepatitis $B$ virus and hepatitis $C$ virus infections to cirrhosis and primary liver cancer worldwide. J Hepatol. 2006;45(4):529-38. PMID: 16879891. Available from: 10.1016/j.jhep.2006.05.013.

6. Fagoonee S, Famulari ES, Silengo L, Camussi G, Altruda F. Prospects for adult stem cells in the treatment of liver diseases. Stem Cells Dev. 2016;25(20):1471-82. PMID: 27503633. Available from: $10.1089 / \mathrm{scd} .2016 .0144$.

7. Burns CE, Zon LI. Portrait of a stem cell. Dev Cell. 2002;3(5):612-3. PMID: 12431368. Available from: 10.1016/ S1534-5807(02)00329-5.

8. Singh P, Williams DJ. Cell therapies: realizing the potential of this new dimension to medical therapeutics. J Tissue Eng Regen Med. 2008;2(6):307-19. PMID: 18618613. Available from: 10.1002/term.108.

9. Kumar A, Pati NT, Sarin SK. Use of stem cells for liver diseasescurrent scenario. J Clin Exp Hepatol. 2011;1(1):17-26. PMID: 25755306. Available from: 10.1016/S0973-6883(11)60114-X.

10. Godfrey KJ, Mathew B, Bulman JC, Shah O, Clement S, Gallicano Gl. Stem cell-based treatments for Type 1 diabetes mellitus: bone marrow, embryonic, hepatic, pancreatic and induced pluripotent stem cells. Diabet Med. 2012;29(1):14-23. PMID: 21883442. Available from: 10.1111/j.1464-5491.2011. 03433.x.

11. Dai LJ, Li HY, Guan LX, Ritchie G, Zhou JX. The therapeutic potential of bone marrow-derived mesenchymal stem cells on hepatic cirrhosis. Stem Cell Res (Amst). 2009;2(1):16-25. PMID: 19383405. Available from: 10.1016/j.scr.2008.07.005.

12. Weissman IL. Translating stem and progenitor cell biology to the clinic: barriers and opportunities. Science. 2000;287(5457):1442-6. PMID: 10688785. Available from: $10.1126 /$ science.287.5457.1442.

13. Tomar GB, Srivastava RK, Gupta N, Barhanpurkar AP, Pote ST, Jhaveri $\mathrm{HM}$, et al. Human gingiva-derived mesenchymal stem cells are superior to bone marrow-derived mesenchymal stem cells for cell therapy in regenerative medicine. Biochem Biophys Res Commun. 2010;393(3):377-83. PMID: 20138833. Available from: 10.1016/j.bbrc.2010.01.126.

14. Kazmi A, Kazmi A, Muhammad W, Azhar M. Mesenchymal stem cells transplantation reduces diabetic nephropathy. Prog Stem Cell. 2019;6(1):260-8. Available from: 10.15419/psc. v6il.403.

15. Soleimani M, Abbasnia E, Fathi M, Sahraei H, Fathi Y, Kaka G. The effects of low-level laser irradiation on differentiation and proliferation of human bone marrow mesenchymal stem cells into neurons and osteoblastsin vitro study. Lasers Med Sci. 2012;27(2):423-30. PMID: 21597948. Available from: 10.1007/ s10103-011-0930-1. 
16. Cao H, Yang J, Yu J, Pan Q, Li J, Zhou P, et al. Therapeutic potential of transplanted placental mesenchymal stem cells in treating Chinese miniature pigs with acute liver failure. BMC Med. 2012;10(1):56. PMID: 22673529. Available from: 10.1186/ 1741-7015-10-56.

17. Zhang D, Jiang M, Miao D. Transplanted human amniotic membrane-derived mesenchymal stem cells ameliorate carbon tetrachloride-induced liver cirrhosis in mouse. PLoS One. 2011;6(2):e16789. PMID: 21326862. Available from: 10.1371/ journal.pone.0016789.

18. Medina J, Moreno-Otero R. Pathophysiological basis for antioxidant therapy in chronic liver disease. Drugs. 2005;65(17):2445-61. PMID: 16296871. Available from: 10. 2165/00003495-200565170-00003.

19. Bhowmik D, Chiranjib K, Kumar S. A potential medicinal importance of zinc in human health and chronic. Int J Pharm. 2010;1(1):05-11.

20. Khan M, Mohsin S, Khan SN, Riazuddin S. Repair of senescent myocardium by mesenchymal stem cells is dependent on the age of donor mice. J Cell Mol Med. 2011;15(7):1515-27. PMID: 20041970. Available from: 10.1111/j.1582-4934.2009.00998.x.

21. Oyagi S, Hirose M, Kojima M, Okuyama M, Kawase M, Nakamura T, et al. Therapeutic effect of transplanting HGF-treated bone marrow mesenchymal cells into $\mathrm{CCl} 4$-injured rats. J Hepatol. 2006;44(4):742-8. PMID: 16469408. Available from: 10.1016/j.jhep.2005.10.026.

22. George J, Tsutsumi M, Takase S. Expression of hyaluronic acid in $\mathrm{N}$-nitrosodimethylamine induced hepatic fibrosis in rats. Int J Biochem Cell Biol. 2004;36(2):307-19. PMID: 14643895. Available from: 10.1016/S1357-2725(03)00253-X.

23. Hernandez-Gea V, Friedman SL. Pathogenesis of liver fibrosis. Annual review of pathology: mechanisms of disease. 2011;6:425-56. Available from: 10.1146/annurev-pathol011110-130246.

24. Li L, Hu Z, Li W, Hu M, Ran J, Chen P. Establishment of a standardized liver fibrosis model with different pathological stages in rats. Gastroenterology research and practice. 2012;2012. Available from: 10.1155/2012/560345.

25. Tuerk MJ, Fazel N. Zinc deficiency. Curr Opin Gastroenterol. 2009;25(2):136-43. PMID: 19528881. Available from: 10.1097/ MOG.0b013e328321b395.

26. Ho E. Zinc deficiency, DNA damage and cancer risk. J Nutr Biochem. 2004;15(10):572-8. PMID: 15542347. Available from: 10.1016/j.jnutbio.2004.07.005
27. Bray TM, Bettger WJ. The physiological role of zinc as an antioxidant. Free Radic Biol Med. 1990;8(3):281-91. PMID: 2187766. Available from: 10.1016/0891-5849(90)90076-U.

28. Yoshioka H, Onosaka S. Zinc sulfate pretreatment prevents carbon tetrachloride-induced lethal toxicity through metallothionein-mediated suppression of lipid peroxidation in mice. Fundamental Toxicological Sciences. 2016;3(4):1516. Available from: 10.2131/fts.3.151

29. Manibusan MK, Odin M, Eastmond DA. Postulated carbon tetrachloride mode of action: a review. J Environ Sci Health Part C Environ Carcinog Ecotoxicol Rev. 2007;25(3):185-209. PMID: 17763046. Available from: 10. 1080/10590500701569398.

30. Ayatollahi M, Hesami Z, Jamshidzadeh A, Gramizadeh B. Antioxidant effects of bone marrow mesenchymal stem cell against carbon tetrachloride-induced oxidative damage in rat livers. Int J Organ Transplant Med. 2014;5(4):166-73. PMID: 25426285.

31. Kumar RS, Sivakumar T, Sivakumar $P$, Nethaji R, Vijayabasker $M$, Perumal $P$, et al. Hepatoprotective and in vivo antioxidant effects of Careya arborea against carbon tetrachloride induced liver damage in rats. Int J Mol Med Adv Sci. 2005;1(4):418-24.

32. Rungruang $T$, Kaewkongkwan $Y$, Sukakul $T$, Kettawan $A$, Chompoopong S, Boonmars $\mathrm{T}$. The effect of vitamin $\mathrm{C}$ on morphology and histology of liver and spleen of Plasmodiuminfected mice. Int Food Res J. 2013;20(4).

33. Yachi $\mathrm{R}$, Igarashi $\mathrm{O}$, Kiyose $\mathrm{C}$. Protective effects of vitamin $E$ analogs against carbon tetrachloride-induced fatty liver in rats. J Clin Biochem Nutr. 2010;47(2):148-54. PMID: 20838570. Available from: $10.3164 /$ jcbn.10-35.

34. Cho KA, Woo SY, Seoh JY, Han HS, Ryu KH. Mesenchymal stem cells restore $\mathrm{CCl} 4$-induced liver injury by an antioxidative process. Cell Biol Int. 2012;36(12):1267-74. PMID: 23035905 Available from: 10.1042/CBI20110634.

35. Marchesini G, Fabbri A, Bianchi G, Brizi M, Zoli M. Zinc supplementation and amino acid-nitrogen metabolism in patients with advanced cirrhosis. Hepatology. 1996;23(5):1084-92. PMID: 8621138. Available from: 10.1002/hep.510230523.

36. Nasir GA, Mohsin S, Khan M, Shams S, Ali G, Khan SN, et al. Mesenchymal stem cells and Interleukin- 6 attenuate liver fibrosis in mice. J Transl Med. 2013;11(1):78. PMID: 23531302. Available from: 10.1186/1479-5876-11-78. 